IRSH 58 (20I3), Special Issue, pp. 6I-85 doi:I0.10I7/So0208590I 3000266 (C) 2013 Internationaal Instituut voor Sociale Geschiedenis

\title{
International Radicalism, Local Solidarities: The 1797 British Naval Mutinies in Southern African Waters
}

\author{
NICOLE ULRICH \\ History Department, Rhodes University \\ Grabamstown I640, South Africa \\ E-mail: n.ulrich@ru.ac.za
}

\begin{abstract}
AвSTRAct: This article details the 1797 mutinies in the British Royal Navy in southern African waters at Simon's Bay and Table Bay at the Cape of Good Hope. Drawing attention to the intersections between international protest during the age of revolution and between local, African protest, it shows that the Cape mutinies were part of an empire-wide strike, and were rooted in the organizational traditions of naval sailors. Yet, these mutinies were also of local significance. They signalled the growing confidence, and radicalization, of the popular classes at the Cape, as sailors, KhoiSan labourers, and slaves all experimented with new strategies of rebellion. Realizing the fundamental class bias of custom and law during their struggles for improvements in wages and working conditions and for a more democratic workplace regime, naval sailors also contributed to a broader political dialogue at the Cape concerning the relationship between the imperial state, freedom, and rights.
\end{abstract}

\section{INTRODUCTION}

Towards the end of 1797, Thomas Kelly of the carpenters' crew on HMS Jupiter was ordered to appear before a court martial for mutinous behaviour. Kelly threatened that:

$[\ldots]$ he was a Delegate and sent by [...] His Company and the Voice of the Ship's Company was not to be played with. He said that a man's life was not so easily taken away now as it was four months ago. The Prisoner desired me [Captain Losack] to recollect Simon's Bay and England, and that the Times were not now as the[y] had been. ${ }^{\mathrm{I}}$

I. National Archives, Kew [hereafter NA], Admiralty Records [hereafter ADM], I/5488, Minutes of Proceedings of a Court Martial Assembled and Held on Board His Majesty's Sloop Rattlesnake on Table Bay on Saturday the Ninth Day of December I797, p. 288. 
Kelly was referring to the 1797 mutinies by naval sailors at Spithead and Nore in Britain, and also to the mutinies that had taken place in southern African waters at the Cape of Good Hope. The Cape mutinies were not isolated protests, and this article examines both the local and international dimensions of the Simon's Bay mutiny (7-I2 October 1797) and the Table Bay mutiny (7 November 1797).

The Cape mutinies were, at one level, inspired by, and in many ways resembled, the Spithead mutiny. As in the case of Spithead, sailors in Simon's Bay organized democratically across the squadron. Drawing on the rhetoric of "free-born Englishmen", 2 sailors attempted to hold their officers to account, and to force the Admiralty to implement significant improvements. However, the mutiny and subsequent court martial of one Captain Stephens, accused by sailors of oppression and neglect of duty, ${ }^{3}$ radicalized sailors rather than reinforced their loyalty. The earlier notion that rights resided in English tradition and law no longer seemed appropriate, as sailors now questioned the legitimacy of naval custom and the courts, leading to the second mutiny in Table Bay. At another level, the mutinies at the Cape also signalled a further upsurge in local, popular resistance, and were followed by the Servants' Rebellion in 1799 and a revolt against slavery in I 808. All of these protests, which represent the Cape's age of revolution, posed a significant challenge to the existing order, as the popular classes experimented with new strategies and new ideas about the relationship between rights, freedom, and the imperial state.

\section{THE CAPE COLONY}

The Cape's popular classes consisted of slaves (either locally born, or imported from Asia, India, and other parts of Africa), indigenous KhoiSan labourers, ${ }^{4}$ sailors, and soldiers mainly recruited from Europe. To understand how these labourers fitted together, it is necessary to briefly outline the Colony's history and political economy.

The Cape of Good Hope was colonized by the Dutch East India Company (the Verenigde Oost-Indische Compagnie, or VOC) in 1652 , and moved into the British imperial orbit briefly from 1795-1803, and then decisively from i 806 . The Colony, located at the southernmost tip of the African continent, straddled the Atlantic and Indian oceans and served as a junction between Africa, Europe, and Asia.

2. E.P. Thompson, The Making of the English Working Class (Harmondsworth, 1963), pp. 84-1 Io. 3. NA, ADM, I/5488, Letter of Charges Against George Hopewele Stephens of HMS Tremendous, I7 October 1797, p. 4.

4. I am using the term KhoiSan, as opposed to Khoisan, to emphasize that this term does not refer to a specific ethnic/racial group, and in order to give equal weight to the pastoralists (Khoi/Khoikoi) and hunter-gatherers (San people) included in the term. 
The Cape's economy was divided into three sectors, each with a specific labour system. The Colony was established to function as a refreshment station for VOC fleets travelling between the Netherlands and Batavia (now Jakarta). Not surprisingly then, the urban economy was portcentred and dominated by the Company, the Colony's largest employer. There were about 3,000-4,000 Company servants stationed at the Cape. The Company hired a small number of skilled workers and artisans, but the majority of these servants consisted of low-ranking sailors and soldiers who staffed the local garrison and fleet. They were bonded by 3-7-year contracts. Any attempt to break the contract, or to desert, was met with severe punishment and, in some cases, death. It is for this reason that these contracts can be characterized as a form of indenture, and the majority of the VOC's servants can be seen as unfree labour.

In addition to recruiting men from across Europe, especially Germany and Scandinavia, the VOC also increasingly relied on Asian sailors to crew homeward-bound ships. In 1792, out of the I,4I7 sailors who sailed from Asia to Cape Town, 233 were Indians, IOI Javanese, and 504 Chinese. $^{6}$ Soldiers were equally diverse in terms of origin, and a separate KhoiSan regiment (the "Hottentot's Corps") augmented the local garrison, which included significant numbers of Germans and Scandinavians. ${ }^{7}$ Added to this, the Company owned about I,000 slaves, who served as domestic labourers or worked at the docks, on public works, and Company outposts. The rest of the urban population consisted of free burghers, ${ }^{8}$ and small groupings of "free blacks" involved in retail (running taverns, eating houses, and boarding houses), small manufacturing businesses, or fishing. They relied on the labour of privately owned slaves, or the "free" poor.

The second sector of the colonial economy comprised grape and grain farms, located in the fertile hinterland and worked by privately owned slaves, assisted by a small number of KhoiSan labourers. Compared to the plantations in the Americas, slave holdings at the Cape were relatively small. Few farmers owned more than 50 slaves at one time. Nevertheless, privately owned slaves still slightly outnumbered slaveholders. In 1773 the Cape Colony was home to approximately 8,902 private slaves (both urban and rural), compared with 8,465 free burghers. ${ }^{1 \circ}$ By the beginning

5. N. Worden, E. van Heyningen, and V. Bickford-Smith, Cape Town: The Making of a City (Kenilworth, 2004), p. 49.

6. Ibid., p. 5 I.

7. J. Parmentier and J. de Bock, "Sailors and Soldiers in the Cape: An Analysis of the Maritime and Military Population in the Cape Colony during the First Half of the Eighteenth Century", in N. Worden (ed.), Contingent Lives: Social Identity and Material Culture in the VOC World (Cape Town [etc.], 2007), pp. 549-558, 556.

8. Company servants released from their contracts to take up farming, and their descendants.

9. Freed slaves and convicts, and their descendants.

ı. N. Worden, Slavery in Dutch South Africa (Cambridge [etc.], 1985), p. I I. 
of the nineteenth century, about 40 per cent of slaves were locally born. ${ }^{\text {II }}$ The remainder were imported. Slaves were initially sourced from parts of Indonesia and India, but towards the end of the eighteenth century the Company mainly sourced new slaves from East Africa, especially Mozambique. Successful wine and grain farmers became exceptionally wealthy. Together with licensed retailers and high-ranking VOC officials, they constituted the Colony's elite.

Finally, a stock-farming sector was located on the Colony's outskirts, and bled into an unsanctioned hunter-raider-trader economy on the colonial borderlands. This kind of farming required substantially less capital and labour than arable farming, but also yielded lower returns. ${ }^{{ }^{2}}$ There was a grouping of wealthy stock farmers, but most were fairly modest, wandering pastoralists (trekboers). Although there were stock farmers who owned one or two slaves, they were dependent mostly on KhoiSan labour. ${ }^{13}$ KhoiSan labourers preferred to accumulate resources over a relatively short period before returning to their pastoralist or hunter-gatherer communities, and they resisted entering into binding, long-term contracts. The bargaining power of KhoiSan was eroded by colonial dispossession, and violence, and they were increasingly forced into labour. In 1775 the first regulations officially indentured KhoiSan children. ${ }^{\mathrm{I}}$

There is a tendency in the literature to treat the labourers associated with each particular sector as geographically and socially separate. Reflecting the persistent fixation on race in South African historiography even today, historians have also tended to treat different sections of the popular classes as distinct racial groups. However, there were always opportunities for labourers to move across sectors, or to other parts of the Colony, and, in so doing, to forge social connections that transcended race, nation, and ethnicity.

The most notable site of connection was the popular culture of leisure ${ }^{\text {is }}$ that centred on the town's dockside taverns and eating houses. Including sailors, soldiers, and urban slaves, men and women from different races

I I. R. Shell, Children of Bondage: A Social History of the Slave Society at the Cape of Good Hope, 1652-I838 (Johannesburg, 200I), p. 47; J. Armstrong and N. Worden, "The Slaves, I652-1834", in R. Elphick and H. Giliomee (eds), The Shaping of South African Society, I652-I840 (2nd edn, Cape Town, I989), pp. I09-183, I 32.

I 2. L. Guelke, "Freehold Farmers and Frontier Settlers, 1657-1780", in Elphick and Giliomee, Shaping of South African Society, pp. 66-108, 89, 92.

I3. Including those who were partly descended from slaves, or Europeans, and acculturated KhoiSan known as Oorlams.

I4. R. Elphick and V.C. Malherbe, "The Khoikhoi to I 828", in Elphick and Giliomee, Shaping of South African Society, pp. 3-65, 32.

I 5 . For the early nineteenth century see A. Bank, The Decline of Urban Slavery at the Cape, I806-I 843 (Cape Town, I99I). For the eighteenth century see N. Ulrich, "Counter Power and 
and with different legal statuses were drawn together. It was also here that the local and the "foreign" drank, danced, gambled, and traded stories and stolen/smuggled goods.

Although rural labourers had fewer social opportunities, they were not totally secluded. Slaves and KhoiSan labourers, in both town and countryside, were hired out regularly. This allowed labourers from different workplaces and districts to mingle, and cross the urban-rural divide. As pasgangers, ${ }^{16}$ sailors and soldiers stationed at the Cape worked on farms, and on occasion could also be found in the countryside. Finally, those living in more isolated parts of the Colony regularly met guides and wagon drivers, occupations dominated by KhoiSan, who must have played an integral role in disseminating local and international news and analysis.

Such opportunities for connection across the regionally based sections of the economy, together with a shared experience of exploitation under harsh labour regimes primarily predicated on the gallows, facilitated the emergence of a distinct popular culture from relatively early on in the Colony's history. ${ }^{17}$ This culture was held together by social and familial bonds, and practices of mutual aid, creating the basis for a class-based identity, and broader political solidarity.

\section{THE AGE OF REVOLUTION AT THE CAPE}

Traditionally, scholars have treated the Cape as the harbinger of the later country of South Africa, into which it was incorporated in I9Io, and the Cape has typically been studied in isolation from the wider world, with an emphasis on the exceptional nature of colonial society and the origins of apartheid in South Africa. More recently historians have started to criticize this treatment of the Cape as the first chapter in a nationally bounded past for obscuring its historical role as a node in imperial circuits of trade and labour. ${ }^{18}$ This analysis can be extended - the Cape's unique location and its incorporation into the Dutch and British empires also ensured that the Colony was part of significant global developments. This study argues that the Cape was influenced and contributed to the age of revolution.

The age of revolution was a time of heightened political and social turmoil that unleashed far-reaching change. At the heart of this turmoil was an intense class conflict in which the popular classes played a leading

Colonial Rule in the Eighteenth-Century Cape of Good Hope: Belongings and Protest of the Labouring Poor" (Ph.D. dissertation, University of the Witwatersrand, 20I I).

I6. Low-ranking Company servants could pay the Company so that others could take on their duties while they earned money in other capacities.

I7. Ulrich, "Counter Power and Colonial Rule", pp. Iо0-I40.

18. The most notable study is K. Ward, Networks of Empire: Forced Migration in the Dutch East India Company (Cambridge, 2009). Also see the essays in Worden, Contingent Lives. 
role in toppling anciens régimes, and in promoting radical political ideas. ${ }^{19}$ The age of revolution was not confined to the North Atlantic. ${ }^{20}$ Significant social conflict took place in parts of Asia and, as this article will show, in southern Africa. Due to the technologies of trade, transport, and communication of the time, the maritime world of ships and ports (such as the Cape of Good Hope) were absolutely central to the circulation of new, radical ideas, and dissemination of information amongst the popular classes about the toppling of imperial powers, monarchies, and the end of slavery.

At the Cape, the first manifestations of far-reaching political and social transformation can be seen in the late eighteenth century, with the decline of the VOC. An internal debt crisis, increasing competition from the British East India Company in the Indian Ocean, and losses sustained during the Fourth Anglo-Dutch War (I780-I784) all contributed. However, the Company's decline cannot be attributed only to external factors, and locally VOC rule was also undermined by fierce political contestation. Historians have noted the challenge spearheaded by the Cape Patriots, the gentry's rally for greater political representation, as well as that of the rebellious frontier free burghers, who dreamed of a republic. ${ }^{2 I}$ Not previously acknowledged in the literature is that the popular classes at the Cape also mounted a series of profound challenges. This omission in the literature is curious, especially since these challenges proved much more destabilizing, and posed a serious threat to the existing order.

This omission in the literature arises from the insistence by many historians that the popular classes primarily resisted their conditions through "informal" and individualized forms of protest. ${ }^{22}$ However, a broader conception of popular resistance - that includes an examination of individual and collective defiance - reveals that popular protest intensified from about the I770s onwards.

Popular revolt was not necessarily land-bound. Mutinies on VOC ships that took place near the Cape were often tried locally. Those on land also believed that they could capture ships and sail to freedom. Ever since

19. This argument has already been made by: P.A. Kropotkin, The Great French Revolution, 1789-1793 (London, I909); C.L.R. James, The Black Jacobins: Toussaint L'Ouverture and the San Domingo Revolution (New York, I938); P. Linebaugh and M. Rediker, The Many-Headed Hydra: Sailors, Slaves, Commoners, and the Hidden History of the Revolutionary Atlantic (Boston, MA, 2000).

20. C.A. Bayly, The Birth of the Modern World, I780-19I4 (Malden, MA, 2004), pp. 89-9I.

21. G. Schutte, "Company and Colonists at the Cape, I652-1795", in Elphick and Giliomee, Shaping of South African Society, pp. 283-323. See also G. Schutte, De Nederlandse Patriotten en de Koloniën: een Onderzoek naar hun Denkbeelden en Optreden, I770-I800 (Groningen, 1974).

22. See R. Ross, Cape of Torments: Slavery and Resistance in South Africa (London, 1983); and N. Worden, "Revolt in Cape Colony Slave Society", in E. Alpers, G. Campbell, and M. Salman (eds), Resisting Bondage in Indian Ocean Africa and Asia (London [etc.], 2007), pp. 10-23. 
soldiers from the local garrison, "a black convict", "two servants of freemen", and some slaves attempted to seize the Erasmus in 1659 , protest in Cape waters mainly took the form of mass desertion by ship (or piratical seizure). ${ }^{23}$

By the 1780 s, mutiny in Cape waters started to take on new dimensions, fuelling upper-class anxieties concerning the Asian crewmen upon which the Company was growing ever more reliant. In 1784 Chinese sailors on the Java mutinied, and a conspiracy was also uncovered amongst slaves on the Slot ter Hoge (travelling in the same fleet as the Java). ${ }^{24}$ Officers on the Slot ter Hoge were particularly concerned that the conspiracy amongst slaves had spread to Asian sailors. This suggests that, as in the case of the North Atlantic, authorities felt threatened by alliances between slaves and sailors.

KhoiSan labourers also challenged their masters, and from the I770s deserted in increasing numbers to join armed bands that raided frontier farms. By the 1780 s some bands were several hundred strong, and in the I790s there was a report of a band that had grown to almost $1,000 .{ }^{25}$ Independent KhoiSan bands were often motley, including runaways from the Colony or neighbouring African communities, and were primarily motivated by a rejection of colonial rule and class exploitation. By the I780s, anti-colonial action started to take on new forms when the prophet Jan Parel and 400 of his followers (mainly KhoiSan, but also a few slaves and free blacks in the Overberg region) combined millenarianism with a "revelation" of revolution. ${ }^{26}$ Parel predicted that the world would end on 25 October 1788 (a year before the French Revolution), ushering in an era of utopian bliss, and the end of colonial rule.

Slaves also questioned their bondage. In the early i790s, a number of cases were heard by the Council of Justice that showed that slaves no longer accepted the total authority of their masters, and they simply refused to conform to established practices of deference. One slave, Mentor van Mozambique, refused to greet any slave owner other than his own master and mistress, ${ }^{27}$ thus rejecting the authority of the broader slave-owning community over individual slaves. Abraham van Macassar,

23. Johan Jacob Saar in R. Raven-Hart (ed.), Cape Good Hope: 1652-1702: The First 50 Years of Dutch Colonisation as Seen by Callers (Cape Town, I971), pp. 58-67, 64-65.

24. K. van der Tempel, “Wij, hebben amok in ons schip': Aziaten in opstand tijdens drie terugreizen op het einde van de achttiende eeuw", in J.R. Bruijn and E.S. van Eyck van Heslinga (eds), Muiterij: Oproer en Berechting op Schepen van de VOC (Haarlem, I980), pp. I23-I47. 25. S. Marks, "KhoiSan Resistance to the Dutch in the Seventeenth and Eighteenth Centuries", Journal of African History, I3 (1972), pp. 55-80, 74.

26. R. Viljoen, “Revelation of a Revolution': The Prophecies of Jan Parel, Alias Onse Liewe Heer", Kronos, 2 I (1994), pp. 3-I 5, 5.

27. Western Cape Provincial Archive [hereafter WCPA], I/ STB/ 3/I2, Criminele Verklarringen, 1786-1793, transl. in N. Worden and G. Groenewald, Trials of Slavery: Selected 
even refused to greet his own masters, claiming that "if I do my work during the day and come home in the evening, that is enough". ${ }^{28}$ Most astounding were the actions of Caesar from Madagascar, who demanded his right to speak when his owner objected to his insolence and ordered him to be quiet. ${ }^{29}$ Convinced that even slaves had rights, Caesar exclaimed "I do not want to be silent, and I must retain my right to speak." ${ }^{\circ}$

Some sailors, soldiers, and slaves at the Cape could read and write, but they left little documentation of their movements, or ideas. There was also no press of any significance that reported on their actions. This means that we have to discern popular, political desires and conceptions of freedom from rebellious acts, or from government records, and the sporadic accounts of elites. Although our view of popular protest at the Cape is fragmented, it is clear that from the I770s the popular classes rejected colonial rule and class exploitation, and sought to curb the authority of their masters.

\section{ENTER THE BRITISH}

The VOC was effectively closed in I796. The Cape itself came under British occupation from I 795 to I 803 and again from I 806 to I 8 I 4 , with an interim period of Batavian rule from 1803 to 1806 . With British rule came political and economic change, including the introduction of a large number of new sailors and soldiers to the Cape.

Historians view the "transition period" (I795-I8I3) narrowly as a successive change in government, and stress institutional continuity in this period. ${ }^{3 \mathrm{I}}$ However, British rule represented a far greater change. The patrimonial system of the VOC was replaced by a new form of state-led imperialism, with a much more intrusive and centralized state under the direct control of the British War Office.

British authorities also championed the protection of private property and free trade, and a new class of British merchants soon arrived to exploit new trading opportunities. Through their linkages with London markets, these merchants played an important role in stimulating commerce and production, with access to credit and financial institutions. ${ }^{32}$ Released from the monopoly of the VOC, local elites quickly pledged their allegiance

Documents Concerning Slaves from the Criminal Records of the Council of Justice at the Cape of Good Hope, 1705-I794 (Cape Town, 2005), p. 608.

28. WCPA, CJ 499, Criminele Process Stukken, I792-I794, fos 419-42 I, transl. in Worden and Groenewald, Trials of Slavery, p. 618.

29. WCPA, CJ 796, Sententiën, 1790-1794, fos 279-284, transl. in Worden and Groenewald, Trials of Slavery, p. 6I4.

30. Ibid.

3I. W. Freund, "The Cape under the Transitional Governments, I795-I8I4", in Elphick and Giliomee, Shaping of South African Society, pp. 324-357.

32. T. Keegan, Colonial South Africa and the Origins of the Racial Order (Cape Town, 1996), p. 50. 


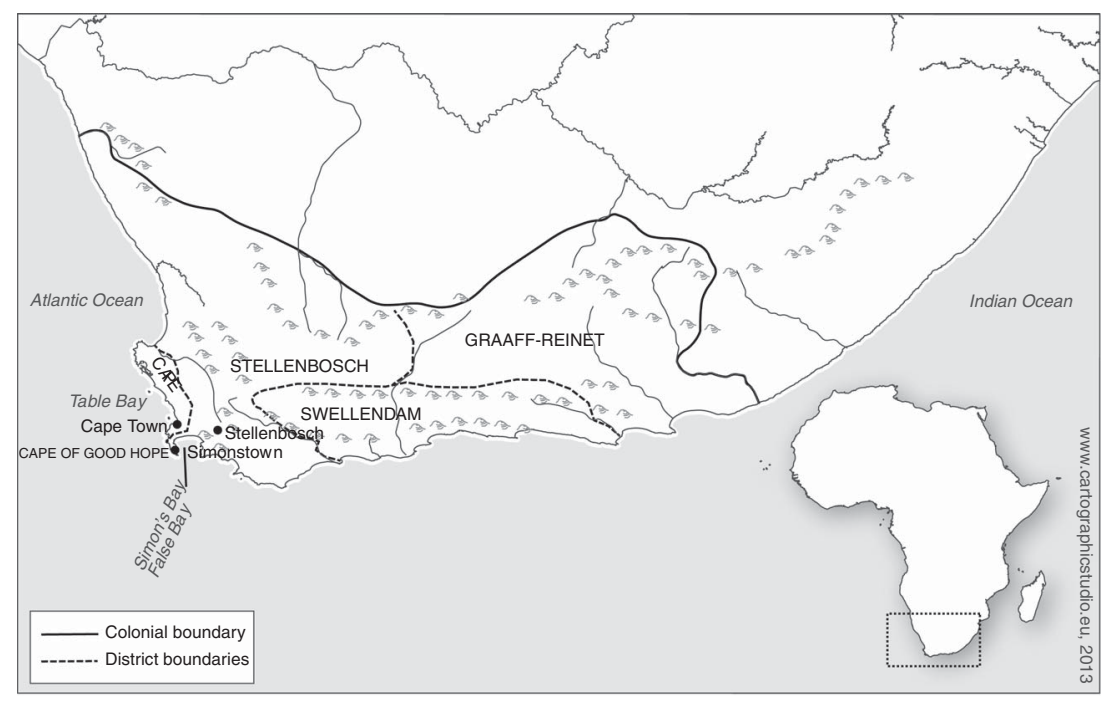

Figure I. The Cape Colony during the first British occupation (1795-1803).

Based on a map in Elphick and Giliomee, Shaping of South African Society, p. 326.

to the British Empire and formed economic and even familial alliances with British merchants and high-ranking officials.

During the Napoleonic wars, the British did not view the Cape simply as a refreshment post, as the VOC had done, but also as a strategic military station. For instance, in 1797 the Earl of Macartney (Cape Governor from May I797 to November 1798) wrote:

Its chief importance to us arises from its geographical position, from its forming the master link of connection between the western and eastern world, from it being the great outwork of our Asiatic commerce and India Empire, and above all from the conviction, if in the hands of a powerful enemy, it might enable him to shake to the foundation, perhaps overturn and destroy the whole fabrick [sic] of our oriental opulence and dominion. ${ }^{33}$

In line with this military focus, local labourers were soon joined by thousands of additional sailors, and soldiers. It is estimated that the British garrison and navy consisted of roughly 5,000 and 3,000 men respectively. ${ }^{34}$ Unfortunately there is no systematic study of these men at the Cape, but my preliminary examination of government records and

33. Letter from the Earl of Macartney to the Right Honourable Henry Dundas, Castle of Good Hope, ro July 1797, in G.M. Theal (ed.), Records of the Cape Colony, I793-18 II, 7 vols (London, I 897-I 905), Manuscript Documents in the Public Record Office, London, Printed for the Government of the Cape Colony) [hereafter RCC], II, p. I I4.

34. Worden et al., Cape Town, p. 93. 
muster books indicates that "British" sailors and soldiers were a diverse lot and included Scots, Irishmen, northern Englishmen, Europeans (especially Dutch and Scandinavians), lascars from India, and a sprinkling of sailors recruited from the West Indies and the Americas.

Largely due to religious nonconformists, and to Enlightenment debates around equality, natural laws, and the inherent rights of man, increasing numbers of "respectable" men and women were convinced of the immorality of slavery. ${ }^{35}$ One consequence at the Cape was the reform of the criminal justice system - one of the main instruments used to discipline labour at the Cape - and the repeal of legislation that permitted torture. For most elites, however, the aim was not to free labour but to regulate various forms of unfree labour more effectively. The trade in slavery flourished under British rule, and after the slave trade was abolished across the Empire a brisk trade in indentured servants shipped from Britain to the Cape emerged. ${ }^{36}$ It is difficult to judge the exact numbers, but there are indications that at least some sailors in the Royal Navy stationed at the Cape were impressed. ${ }^{37}$

This continued reliance on unfree labour points to an important continuity - as under Dutch rule, most labourers at the Cape were unable to choose their employers or negotiate their wages. Although the most dreadful punishments and tortures had been abolished, the popular classes were still terrorized by harsh and violent measures of control and could still lose their lives if they resisted their masters.

\section{BRITISH SAILORS}

It would appear that naval sailors spent most their time on board, as their ships patrolled the seas. Since there are no studies of these men prior to this article, it is difficult to determine their relations with local labourers. However, we can most certainly identify two key sites of contact.

Much like low-ranking Company servants in the late eighteenth century, British sailors and soldiers became part of the dockside popular

35. M. Craton, J. Walvin, and D. Wright, Slavery, Abolition and Emancipation (London, 1976), pp. 195-199.

36. S. Newton-King, "The Labour Market of the Cape Colony, I807-28", in S. Marks and A. Atmore (eds), Economy and Society in Pre-industrial South Africa (Hong Kong, 1980), pp. $17 \mathrm{I}-207, \mathrm{I} 83$.

37. In the court martial records, deserters continually avoided the harshest forms of punishment because they had not accepted the King's bounty, one indication that they had not joined the navy voluntarily. See, for instance, NA, ADM, I/5487, Minutes of Proceedings of a Court Martial, 2 December 1796, pp. I9-29; or NA, ADM, I/5487, Minutes of Proceedings of a Court Martial, I 8 May 1797, pp. 237-242. There is also the pamphlet by the American Joshua Penny, who deserted at the Cape to escape impressments; J. Penny, The Life and Adventures of Joshua Penny (Cape Town, I982), originally printed by the author in 18 I 5 . 
culture of leisure. By the second British occupation (I806-I 8 I 3 ), taverns and eating houses also became political spaces. It was, after all, in one of Cape Town's taverns that sailors and urban slaves planned the i 808 revolt against slavery, and recruited support from slaves working on farms. ${ }^{38}$

A second significant point of connection was desertion, which had always been, and continued to be, the most common form of popular resistance at the Cape. During both the first and second British occupations, the authorities issued proclamations offering pardons to deserted soldiers and sailors thought to be living in country districts. ${ }^{39}$ Yet, such measures appeared to have little effect. Sailors and soldiers adopted a variety of strategies. Some were found work on frontier farms, and were absorbed into colonial society, while others roamed the Colony, relying on other slaves or labourers for support. There are also indications that some deserters joined the KhoiSan or fugitive bands on the colonial borderlands. For instance, Joshua Penny, an impressed sailor who deserted at the Cape, claimed to have lived with KhoiSan, as did the Irish sailor James Hooper, one of the sailors hanged for his participation in the 1808 revolt against slavery..$^{\circ}$ Travel writer Henry Lichtenstein, who travelled through the Cape during the Batavian period between I 803 and I 806, also confirms these strategies of desertion. He noted that when the Batavian governor, Jan Willem Janssens, toured the Cape he met a number of English deserters, "[s]ome concealed amongst the savages [KhoiSan], some among the colonists". ${ }^{4}$

The new wave of "British" deserters - and sailors and soldiers more generally - were increasingly associated with disorder. Governor Janssens shared these anxieties, and complained of the "extremely pernicious influence" of deserters on local inhabitants..$^{42}$ Even more alarming were the 1797 naval mutinies in Simon's Bay and Table Bay. There can be little doubt that it was these mutinies that initially, and unequivocally, allowed colonial authorities to link sailors and popular disorder.

\section{THE SIMON'S BAY MUTINY}

The Simon's Bay mutiny was inspired by the Spithead mutiny, which took place in April 1797 in English waters. The extent to which the democratic

38. N. Ulrich, "Abolition from Below: The I 808 Revolt in the Cape Colony", in M. van der Linden (ed.), Humanitarian Intervention and Changing Labor Relations: The Long Term Consequences of the Abolition of the Slave Trade (Leiden, 201 I), pp. 193-222.

39. Proclamation by Francis Dundas, 26 February 1799, RCC, II, p. 375; and proclamations by Sir David Baird, 25 January I806, RCC, V, p. 307; 16 May I806, RCC, V, p. 42 I; and Is August I 806, RCC, VI, pp. $25-26$.

40. Penny, Life and Adventures, pp. 19-22.

4I. H. Lichtenstein, Travels in Southern Africa, in the Years I803, I804, I805, and I806, 2 vols, transl. Anne Plumptre (Edinburgh, I8 I 5), I, p. 39I.

42. Ibid. 
nature of sailors' organization and the crews' grievances in Simon's Bay resembled that of Spithead is truly remarkable, and suggests that sailors at the Cape drew on the well-established, egalitarian traditions of naval sailors that were further developed into forms of self-organization during the Spithead and Nore mutinies. ${ }^{43}$ Although VOC crews had sometimes used their mutiny as a form of strike, this had not occurred in Cape waters. Thus, the Simon's Bay mutiny marked a distinct departure from previous modes of maritime protest in the region. Instead of killing their commanding officers and deserting, as had been done in the past, naval sailors forced their admiral to negotiate and implement reforms that improved their conditions.

The first signs of mutiny at the Cape started with "disturbances" on the Vindictive on 2 October $1797 .{ }^{44}$ This was quickly quelled and the Vindictive separated from the rest of the squadron, which served only to enflame the sailors' desire for redress. Another warning of disquiet came on 5 October in the form of an unsigned letter dropped on the deck of the Tremendous. Addressed to Captain Stephens of the Tremendous, it stated that seamen on the Rattlesnake were being abused, and that to "keep disturbance from the fleet" this should be righted on every ship and that there must be no "Bad Usage" or mistreatment of the crew. ${ }^{45}$ Stephens did not react, and on 7 October a jacket was attached on the jib-boom of each naval ship lying in Simon's Bay and, with the customary round of cheers, the Tremendous, Trusty, Imperieuse, Braave, Rattlesnake, Chichester, Star, and Suffolk rose in general mutiny.

This came in the wake of the Spithead mutiny in British waters, which was an astounding success. ${ }^{46}$ There, a fleet-wide mutiny forced the Admiralty to negotiate, and sailors won numerous reforms, which were enacted by Parliament. Spithead delegates received a royal pardon and were officially honoured in the celebrations that followed.

43. For the egalitarian traditions of sailors see M. Rediker, Between the Devil and the Deep Blue Sea: Merchant Seamen, Pirates and the Anglo-American Maritime World, I700-I750 (Cambridge, 1987), and for self-organization at Spithead and Nore, see J.P. Moore, "The Greatest Enormity That Prevails': Direct Democracy and Workers' Self-Management in the British Naval Mutinies of 1797", in C. Howell and R. Twomey (eds), Jack Tar in History: Essays in the History of Maritime Life and Labour (Fredericton, I99I), pp. 76-104.

44. Letter, Rattlesnake Company. It would appear to have been thrown on deck on 5 October I797, RCC, II, pp. I62-I63.

45. Letter, dropped on the quarterdeck of the Tremendous, 7 October 1797, RCC, II, pp. I6I-I62.

46. For the Spithead mutiny see D. Featherstone, "Counter-Insurgency, Subalternity, and Spatial Relations: Interrogating Court-Martial Narratives of the Nore Mutiny of 1797", South African Historical Journal, 6i (2009), pp. 766-787; C. Gill, The Naval Mutinies of 1797 (Manchester, I9I3); G.E. Manwaring and B. Dobree, The Floating Republic: An Account of the Mutinies at Spithead and the Nore in 1797 (London, 1935). 
It is difficult to plot the "spatially stretched knowledge networks" of sailors that transmitted news of the Spithead mutineers' success to naval sailors at the Cape. ${ }^{47}$ One source seems to have been the Arniston, which left Portsmouth in June and arrived at the Cape in August $1797 . .^{4}$ (Interestingly, the Arniston was an English Indiaman, and not a naval ship, which indicates that merchant and naval sailors were somehow connected and that their networks overlapped.)

In the days preceding the Simon's Bay mutiny, the various ship's companies busied themselves passing letters between ships in the squadron and drawing up petitions, which mobilized the sailors around key demands. These letters give us some insight into the nature of the sailors' organization. At Spithead, each of the sixteen line-of-battle ships appointed two delegates to a central committee, and sailors took an oath to stay true to the cause. ${ }^{49}$ Reflecting the egalitarian bonds and democratic practice that had developed amongst sailors across the Royal Navy, and which provided the basis for direct democratic practice and workers' control at Spithead, ${ }^{\circ}$ the Simon's Bay mutineers also organized democratically. Like Spithead, they elected two delegates from each ship and were careful to build support across the squadron.

The company of the Rattlesnake initiated the correspondence between ships, but it was the close horizontal bonds developed between crewmen that laid the foundations for unity. ${ }^{5 \mathrm{I}}$ Sailors spent months, sometimes even years, together and regarded each other as brothers. In the Rattlesnake's initial letter to the Tremendous, and in the subsequent letters passed between the various ships, sailors addressed each other as "brother".52

These sailors' impulse was democratic. The Rattlesnake's company informed their brothers that they had canvassed grievances amongst each other, and that the majority on the ship were determined "to bring the Usurpers of our rights to a just account of their future Transactions, and make or Compel them to render us justice and better usage". ${ }^{33}$ They called on the support of other companies, arguing that "having long laboured under their Yoke - we hope that on this determination of ours we will find you and our other friends agreeable to force those Usurpers into a more lenitive line". ${ }^{54}$

47. Featherstone, "Counter-Insurgency, Subalternity", pp. $766-787,775$.

48. Letter, Lady Anne Barnard, The Castle, Cape Town, is October 1797, in William Henry Wilkins (ed.), South Africa a Century Ago: Letters Written from the Cape of Good Hope (I797-I80I) (London, I910), p. 95.

49. Gill, The Naval Mutinies of 1797, p. 24.

50. Moore, "The Greatest Enormity That Prevails", pp. 84-85.

5. For more on these horizontal linkages see Rediker, Between the Devil and the Deep Blue Sea, and Linebaugh and Rediker, The Many-Headed Hydra.

52. Letter, Rattlesnake Company, RCC, II, p.I62.

53. Ibid.

54. Ibid. 
The Rattlesnake did receive support. Although those on the Tremendous had not experienced similar abuses, and even wrote that they "had no right to complain", they declared that "if you have bad usage we one and all will see you righted".55 The company on the Tremendous, the flagship, did not only pledge solidarity but also coordinated the petitioning and mutiny.

The various companies' statements of complaint show sailors' views of what they regarded as acceptable terms of remuneration and discipline, and their understanding of justice. The grievances raised by the sailors of the Cape station were similar to those raised at Spithead, and centred on the quantity and quality of provisions, on working conditions, on punishment, and on the privileges of rank. Their demands dealt not only with issues related to the belly. Sailors in both English and Cape waters wanted to curb the power of their commanders, and they demanded a more democratic workplace in which sailors had a say in ship discipline.

In terms of rations, all the companies complained about the quality of bread and beef. Those on the Imperieuse indicated that they had received no butter or cheese since they arrived at the Cape, but only rice and sugar. ${ }^{56}$ These were poor substitutes and were not given in adequate quantities. Similarly, the Trusty's company complained that there were no "greens or vegetables to be had and that the peas have been kept back". 57

Most companies believed that the weights and measures used to determine food allowance were fixed short. The seamen on the Braave insisted that the weights and measures had been short for eight to nine months and demanded that the purser "refund us the same".5 ${ }^{8}$ The Imperieuse even declared the conduct of their purser, Mr Dennis, to be fraudulent, and that he "has much abused the confidence he had gained on his superiors to prejudice the navy".59 Concerns were also raised that rations were being withheld without adequate restitution or payment. Of particular concern was that the liquor of all persons on the sick list regardless of the nature of their disease - had been stopped. Although this liquor was supposed to be repaid in money within three months, some men had not been paid for up to a year.

The Trusty called for a stop to all "unnecessary work", such as "holy stoning and washing the decks in the middle of the day", while those on the Braave complained of "very irregular hours" of work, plus the late serving of food. ${ }^{60}$ The Rattlesnake argued that two hours' personal washing a week was hopelessly inadequate, and demanded more recreation time.

56. Imperieuse Company's Grievances, RCC, II, pp. I7I-I72.

57. Trusty Company's Grievances, RCC, II, p. I70.

58. Braave Company's Grievances, RCC, II, pp. I72-I73.

59. Imperieuse Company's Grievances.

60. Trusty Company's Grievances, and Braave Company's Grievances. 
As at Spithead, sailors in Simon's Bay wanted the authority of their officers to be limited. While sailors were willing to put up with a certain amount of harsh language, they rejected rudeness and abusive language when undeserved. The Rattlesnake's crew complained of being "oppressed by young and inexperienced officers, who learned command before they had learned obedience". ${ }^{6 I}$ The crew drew attention to some of the tyrannical and unlawful punishments to which they had been subjected. For instance, a Mr Steward had commanded one man to "ride the spanker broom at sea, with a hand swab for a whip", and had another "lashed across their shoulders and their arms extended with a twelve pound shot hung at each end". ${ }^{62}$ The company also chastised Mr Syms for his "arbitrary command and degrading speeches". ${ }^{63}$ Sailors said that in the harbour Syms would command the hoisting of boats, lowered up to three or four times a night, only to please an "arbitrary ambition", which they believed to be "quite inconsistent with the laws of Britain". ${ }^{64}$

The Rattlesnake's company made it clear: seamen would "allow laws to punish", but would not tolerate "tyrants to bear His Majesty's commission". ${ }^{6}$ "This company demanded that "captains or officers commanding or serving in any of His Majesty's ships shall not harass or oppress subjects of Great Britain in any scandalous or fraudulent manner, unbecoming the character of British officers". ${ }^{66}$ They demanded that the punishment of all misdemeanours should be referred to a majority, with the captain as president, rather than being punished at will by officers.

Finally, sailors also questioned the privileges attached to rank. As the men on the Rattlesnake stated, "[w]e would wish as all defending one cause to have the same share that is allowed of provisions without any respect to be paid to any person, rank, or quality". ${ }^{67}$ Expressed more plainly, those on the Trusty wanted some "redress respecting the different officers having the prime of the meat, and that they will have mutton only every third day the same as the ship's company". ${ }^{68}$ The Braave expressed similar sentiments about the distribution of meat, complaining that "our officers have been found to take the advantage of us therein by choosing prime pieces" ${ }^{69}$ Sailors clearly wanted to see a more equitable distribution of food on board.

61. Rattlesnake Company's Grievances, RCC, II, pp. I74-176, I74.

62. Ibid.

63. Ibid.

64. Ibid., p. 175 .

65. Ibid.

66. Ibid.

67. Ibid.

68. Trusty Company's Grievances.

69. Braave Company's Grievances. 
The mutineers had the military advantage. The admiral was detained on the Tremendous and the troops that occupied the heights of Simon's Town were no match for the ships' formidable guns. ${ }^{70}$ Pringle had little option but to deal with the sailors' grievances and negotiate a settlement. However, sailors' mistrust of authority ran deep. The sailors' delegates agreed to speak to the admiral, but insisted that "whatever you might have to say to us that you will send the same in writing and we will do the same in return". ${ }^{\text {I }}$ A written record would serve as protection: it could be presented as evidence at court martial, and it prevented the admiral from playing the respective companies against their delegates, and from reneging on his promises.

At first Pringle conceded little. He explained that rations were scarce, that the serving of beef every day was "the custom that had always taken place at the Cape of Good Hope", and that the navy did not allow peas to be issued when beef was served every day. ${ }^{72}$ The only concessions were that he would investigate the non-payment of the carpenters' crew, and that in future the ship's surgeon would decide when it was necessary to stop the liquor allowance of the sick.

The sailors stood firm. They asserted that "the people of this squadron has heard something of the conduct of His Majesty's Fleet in England, and the regulations that has taken place in consequence with regard to extra allowance of pay and provisions" ${ }^{73}$ The companies wanted the same to be implemented in their squadron. They also appealed for a speedy remedy, and demanded that a general amnesty be extended to every individual in the squadron, including those on board the now absent Vindictive.

It should be noted that, much like the mutineers at Spithead, sailors in Simon's Bay were well disciplined and indicated that they would not permit "Pillaging, Pilfering or Riot, or bad Usage given by any of us to either party". ${ }^{4}$ Probably being careful not to be labelled as treasonous they had after all mutinied during a war - the sailors' letters declared their loyalty to the Crown and the British Empire, and indicated that they would return to duty in the case of enemy invasion. ${ }^{75}$

Pringle's explanations of scarcity aside, he was forced to make some changes. In his reply on 9 October, the admiral noted:

70. Letter, Lady Anne Barnard, p. 96.

7I. Letter, Delegates [Enclosure R], RCC, II, p. I84.

72. Admiral's response to the Tremendous [Enclosure E], RCC, II, pp. I68-170, I69.

73. General Statement of the Grievances Complained of by the Different Ships' Crews of the Squadron, RCC, II, pp. I77-179, I78.

74. Ibid.

75. Second Letter, Rattlesnake Company, RCC, II, p. I63. 
It is the pursers' duty to furnish perfectly good weights and measures, and it is that of the commanders to see that they do so, consequently when any deficiency is discovered and reported to the Captain, he must correct the same immediately, as the men are not to be defrauded. ${ }^{76}$

Pringle claimed that a survey of bread had already been ordered, and that he had given orders that the biscuit baked in future would be of the proper quality. Captain Stephens, he said, had already brought the poor quality of beef to his attention, leading to a public order in September that required the butcher and an officer from each ship to attend the killing of cattle. There was also a little rum left in the stores of the Tremendous, which could be served out if required, and should there be any complaints regarding wine and sprits a survey would be ordered and the bad liquor condemned. The tobacco at the Cape was too expensive, but the admiral indicated that should tobacco arrive that could be purchased at a reasonable price, it would be procured.

Even the question of class privilege was addressed to some extent. It had long been custom in the navy for officers to have choice cuts of meat, for which one pound in seven was charged. In line with the sailors' demands, the admiral ordered "that no such thing be permitted to take place in future". ${ }^{77}$

With respect to the fleet at home, Pringle confirmed that he had had no official communications regarding an increase of pay or provisions, but "wished to God" that the ships' companies had exercised patience and waited for such information from England, instead of turning their officers ashore and committing acts "highly repugnant to the laws of their country". ${ }^{8}$ The admiral promised to implement official orders once received, and meanwhile appealed to the companies to recall their officers and return to duty. This would convince him of the propriety of the sailors' intentions and, he argued, smooth the way to a general amnesty.

Bargaining continued, but eventually the sailors were satisfied that the admiral would ensure that the quality of bread was improved, and that he would remedy other complaints. The main area of contention remained the fate of the obnoxious officers sent ashore at the start of the mutiny. The sailors believed that they had sufficient cause for complaint against these officers, and had resolved not to serve under them again "on any terms whatever". ${ }^{79}$ However, the admiral was not prepared to undermine the authority of his officers. Mirroring the sailors' appeal to the law, he maintained that he did not have the authority to simply remove officers

76. Admiral's Response, [Enclosure N], Tremendous in Simon's Bay, 9 October I797, RCC, II, pp. I79-I 8 I, I8I.

77. Ibid., pp. 179-1 8 1, I 80 .

78. Ibid., pp. 179-1 8 I, I 8 I.

79. Reply of the Delegates, [Enclosure O], RCC, II, p. I83. 
without first legally investigating the complaints against them. Pringle appealed for the companies to recall their officers, and to bring forward complaints "in a manly and legal way". ${ }^{\circ \circ}$ Sailors at the Cape were distrustful of the courts, but eventually agreed to the courts martial of officers.

The sailors returned to duty on I 2 October. The royal standard was hoisted on board the Tremendous "as a signal of good order and discipline being established in the fleet". ${ }^{81}$ On the same day, the admiral issued a proclamation granting the pardon and general amnesty to all seamen and marines in the squadron "who so returned to the regular and ordinary discharges of their duty". ${ }^{2}$

\section{CUSTOM AND RIGHTS}

The court martial of the controversial Captain Stephens started a few weeks later, on 6 November, on board the Sceptre in Table Bay. This trial points to a notable shift in the sailors' understanding of rights. Their firm rejection of custom at Stephens's trial signalled a departure from the notion that their rights were rooted in British tradition.

Much like the sailors at Spithead, the sailors in Simon's Bay publically identified themselves as the "lawful and true born subjects of great Britain" and demanded that their "Primitive Rights" should be recovered. ${ }^{83}$ In so doing, these sailors appear to evoke an earlier conception of rights that had previously been articulated by, for example, the Levellers during the English Revolution. According to E.P. Thompson, in the eighteenth century claims to be a "free-born Englishman" were cloaked in a rhetoric of liberty, were made by reference to past - and often local laws and customs, and were made by radicals, patricians, and demagogues alike to justify a range of political agendas. ${ }^{8}{ }^{8}$ Such claims were not so much a demand for democracy as the affirmation of a distinct entitlement to the rule of law, and a shared rejection of absolute, arbitrary power by the state over the gentry and common people. ${ }^{85}$ As noted by Thompson, this particular understanding of rights was fundamentally limited - it implied respect for the monarchy, the hereditary principle, and for the traditional property rights of landowners. ${ }^{86}$

When applied in the context of the Royal Navy, sailors questioned the arbitrary authority exercised by their officers, and called for the

80. Memorandum of the Admiral [Enclosure P], RCC, II, pp. I82-183, I82.

8I. Letter from the Earl of Macartney to the Right Honourable Henry Dundas, Castle of Good

Hope, I3 October 1797, RCC, II, pp. 86-187, I87.

82. Proclamation, by Admiral Pringle [Enclosure U], RCC, II, p. I 86.

83. Letter, Rattlesnake Company.

84. Thompson, The Making of the English Working Class, p. 85 .

85. Ibid., pp. 87, 90.

86. Ibid., p. 96. 
implementation of the law. For instance, the sailors of the Tremendous objected to the list of articles read out on the quarterdeck, which appeared to be different from the Articles of War. The company stated that it did not have a problem with the "general tenor" of such articles that dealt with good order, discipline, and cleanliness. ${ }^{87}$ However, the sailors were of the opinion that "no authority whatever has a right to pose new laws on them except that of the British legislature". ${ }^{88}$

Although sailors deployed this particular rhetoric of "free-born Englishmen", it appears that they also started to recognize the limits of a traditionbound notion of rights when they specifically rejected the notion of naval custom during Stephens's trial. At the heart of this rejection was the belief that custom was a naked instrument of class oppression. For instance, in the charges brought against Stephens, the sailors noted:

The Ships Company are aware that the Customs of the navy will be used in defence of this Charge and That the Ships Company does not appeal to Customs as it has been custom perhaps before the Existence of the British Navy for people in low situations to be opprest [sic] by those in power therefore the purpose of all laws has generally been to protect the weaker members of society. ${ }^{89}$

Correctly anticipated by the sailors, Stephens was a firm supporter of customs, and custom was integral to his legal defence. He argued that "most of the charges against me has been long sanctioned by custom and recommended as well as followed by officers the most distinguished in our service"..$^{\circ}$ Stephens believed that rule through custom was unquestionable. $\mathrm{He}$ argued that, although sailors claimed to have long-standing grievances, they had never complained because they knew it was custom and "therefore to complain of them would appear frivolous and troublesome". ${ }^{91}$ The captain believe that sailors respected custom above all else, and maintained that they had been misled by a few mischievous individuals "to delight in disorder and confusion" and so to follow the example of the fleet in England. ${ }^{92}$

However, even though the captain may have believed that the mutiny could be blamed on a few troublemakers, he admitted that relations between sailors and their officers were starting to change. He claimed that the 1797 mutinies had "removed the tie of Confidence between officers and men and instead there of have taken up distrust, and now nothing is heard of but grievance and complains formerly not known of". ${ }^{3}$

87. Tremendous Company's Grievances, RCC, II, pp. I64-168, I66.

88. Ibid.

89. NA, UK, ADM I/5488, Charges to be Exhibited Against Captain George Hopewele Stephens Esq. Commander of His Majesty's Ship Tremendous, 28 October 1797, pp. 7-8.

90. NA, UK, ADM r/5488, Captain Hopewele Stephens Defence, p. 76.

91. Ibid.

92. Ibid.

93. NA, UK, ADM, I/ 5488 , Minutes of Proceedings of a Court Martial, pp. 87-88. 
Why had sailors at the Cape become so distrustful of naval custom? Common understandings of rights and obligations in the navy could and in many instances probably did - serve as a basis for a moral economy shared by sailors and their officers, which sailors could deploy when conditions and rations deteriorated, or officers became too authoritarian. Joseph Price Moore argues that British naval sailors occupied and moved between two distinct worlds, namely a world of tradition, paternalism, and deference, which allowed for an economy shared by officers and crew, and the world of capitalist relations, which gave rise to new forms of action, such as the strike and a broader class identity. ${ }^{94}$ However, in the case of the Cape, it seems that sailors were no longer able to reconcile these two worlds, and the harsh reality of capitalist relations, together with the need for a broader identity in line with sailors' unity, undermined any possibility of an economy shared by officers and crew, and eroded the legitimacy of British, or naval, custom as a basis for claiming rights.

First, officers continually evoked custom to deny sailors the most basic provisions on the one hand, and to justify their privileges on the other. Pringle complained that the Cape was in short supply of just about everything. In August 1797, just two months before the mutiny, he wrote about the "great distress of the squadron", and that he had never been able to procure bread sufficient for one month for the whole squadron. ${ }^{95}$ Considering these shortages, it was probably just as well that the squadron was some 760 men short (excluding the 60 men in hospital whom he did not expect to recover and return to duty). ${ }^{96}$ Added to this, the quality of slops, beds, and marine clothing was inadequate and Pringle complained that "the men are totally destitute". ${ }^{97}$ However, the sailors did not appear to trust such claims of scarcity. They may have questioned the Navy's tardiness with regard to providing monetary compensation for short provisions, and there seemed to be enough food to supply East India Company ships on their way to St Helena. Indeed, the officers still seemed to enjoy reasonably good rations. Under these circumstances, custom became a justification for failing to meet the sailors' most basic needs, as opposed to a system of reciprocation and redress between officers and crew.

In the second instance, not everyone in the navy could claim to be British-born, nor free. As noted above, "British" sailors were a relatively motley lot. An identification as British subjects could accommodate the multi-racial and multi-national composition of sailors drawn from across

94. Moore, “The Greatest Enormity That Prevails”, pp. 8I-83.

95. Letter, Admiral Pringle to Evan Nepan Esq., Tremendous in Simon's Bay, Cape of Good Hope, I7 August 1797, RCC, II, pp. I $52-155$.

96. Letter, Pringle to Nepan, Tremendous in Simon's Bay, Cape of Good Hope, 25 August 1797, RCC, II, pp. I 56-I 57.

97. Ibid. 
the empire. Even so, this would require the replacement of the parochial rhetoric of "free-born Englishmen" with a more universal notion of rights. Customary "British" rights, in short, could not provide an adequate basis for unifying sailors - something more was required.

Finally, ideas of rights were in the process of being re-conceptualized in the writings of radicals such as Thomas Paine, as well as in the American Revolution (I776-I783) and the French Revolution (I789-I794). In this context, sailors questioned the limited notion that rights resided in British tradition and law, as they too were influenced by, and participated in, discussions regarding the more intrinsic origins of rights derived from Reason, God, or nature, rather than British history.

\section{THE LIMITS OF REFORM}

Like the Spithead mutiny, which was followed by the more radical mutiny at Nore, the Simon's Bay mutiny was followed by a second, more radical phase when naval sailors mutinied in Table Bay on 7 November 1797. It is more difficult to make sense of this mutiny, especially since the only petition drawn up was destroyed..$^{8}$ Nevertheless, the mutiny seems to represent sailors' growing suspicion, not only of class bias inherent in custom but also of the law in which they had placed so much hope just a few weeks previously.

Upper-class individuals such as Lady Barnard, wife of the Secretary of the Colony under the first British occupation, were sorry that a general amnesty had been granted to mutineers at the Cape. She claimed that "even the best-natured people wish the delegates to be made examples of to the Navy". ${ }^{99}$ It soon became apparent that the court martial was not simply about restoring Captain Stephens's name; it was also a means of enabling officers and commanders to reassert their authority.

In spite of the sailors' insistence on the rule of law, they did not trust the courts. It is for this reason that they demanded some representation in cases dealing with sailors' discipline during the Simon's Bay mutiny - a demand the sailors failed to win. The limits of the courts as a basis for popular redress became apparent on 7 November, the second day of the trial, when the court held two sailors in contempt. ${ }^{\circ 00}$ James Hay was apparently drunk, while James Willis - one the delegates from the Tremendous during the Simon's Bay mutiny - was accused of interrupting the court. Both were sentenced to one month's imprisonment.

The court's actions infuriated the sailors. Together with the Jupiter and the Reasonable, the Sceptre had just recently returned from St Helena.

98. NA, ADM, I/5488, Minutes of Proceedings of a Court Martial, 30 November I797, pp. I39, I47, I 50-I 54 .

99. Letter, Lady Anne Barnard, p. 98.

ı०0. NA, ADM, I/5488, Minutes of Proceedings of a Court Martial, pp. 33, 40. 
Officers picked up a mood of rebelliousness amongst sailors on these ships. ${ }^{\text {IOI }}$ The imprisonment of Willis provided the trigger for action and, with three cheers, sailors on the Tremendous, Sceptre, and Rattlesnake, now all in Table Bay, mutinied. They were joined by the Crescent, quarantined off Robben Island on account of a smallpox outbreak on board the Spanish slaver she had just taken as a prize. ${ }^{\text {I02 }}$

This time Admiral Pringle acted together with the Cape governor and the fiscal, the Cape's chief legal officer, to repress the mutiny. They had the military advantage, and aimed the guns of the Amsterdam Battery at the ships. ${ }^{103}$ The mutineers were given an ultimatum: give up their leaders and return to order or they would be fired upon. Left with little option, the leaders were surrendered. After briefly being detained in the castle, they were tried by courts martial. ${ }^{\text {I04 }}$ While the court found Captain Stephens to be innocent of the charges sailors had brought against him, four of the Table Bay mutineers were found guilty and sentenced to death. ${ }^{\text {105 }}$

In spite of the success of the Spithead and Simon's Bay mutinies, much still had to change. Through unity and democratic organization, sailors were able to win real improvements in their basic conditions, but the power and privilege of the upper classes remained intact. Like those at the Nore, sailors at the Cape were quick to recognize the limits of such reforms and were radicalized. Like those at the Nore, mutineers at Table Bay were also punished harshly for daring to oppose their officers.

\section{THE LOCAL CHALLENGE CONTINUES}

The Cape's new rulers were able to win the allegiance of the elite, and used military force to crush rebel free burghers, but the popular classes would prove much more difficult to coopt, or even to defeat militarily. The I 797 mutinies signalled a further upturn in popular protest at the Cape, as well as the development of new popular political strategies. Like the mutineers, KhoiSan and slaves would also adopt new strategies that raised questions about the relationship between rights, the state, and freedom.

Unlike the Servants' Rebellion and the i 808 revolt against slavery, naval sailors did not demand their freedom or a change in government. Yet the Simon's Bay mutiny cannot easily be described as reformist, despite its seemingly more moderate demands. The sailors organized a mutiny across

ıо I. NA, ADM, I/5488, Minutes of Proceedings of a Court Martial, 9 December 1797, pp. $28 \mathrm{I}-302$.

I02. Theal, "Digest of the Records", RCC, V, p. 39, and Letter, Pringle to Nepean, Tremendous, Table Bay, Cape of Good Hope, 27 November 1797, RCC,. II, pp. 206-208.

I03. Letter from the Earl of Macartney to the Right Honourable Henry Dundas, I 2 November I797, RCC, II, pp. 202-203, 202.

104. Letter, Pringle to Nepean, Tremendous, 27 November 1797, RCC, II, pp. 206-208.

I05. RCC, V, pp. 39-40. 
the squadron during wartime - an act that could easily be interpreted as treasonous. In addition, some of their demands, especially those related to limiting officers' privileges and authority, and the creation of a more democratic and egalitarian workspace, were actually quite radical. Most significantly, the Simon's Bay and Table Bay munities were continuations of the remarkable experiment on the part of sailors with direct democracy and workers' control during the Spithead and Nore mutinies. Sailors had succeeded in using militant, democratic protest to engage the Admiralty and to force the state to make substantial changes.

Even though the Table Bay mutiny ended in the execution of radicals, mutinies continued to take place in Cape waters. These included a mutiny by soldiers on board the Lady Shore en route to Botany Bay; a mutiny by the crew of the Princess Charlotte belonging to the East India Company; and a mutiny on board HMS Hope in I 800 , just off the coast of Madagascar. ${ }^{106}$

Just as significantly, the 1797 mutinies marked a growing confidence and radicalization of the popular classes at the Cape, which resulted in a further upturn in resistance and also the willingness to experiment with new strategies and ideas. From I799 KhoiSan labourers deserted their masters on an unprecedented scale, only to raid outlying farms for arms, ammunition, and horses. ${ }^{107}$ By the end of July 1799 KhoiSan bands were in control of the whole south-eastern part of the Graaff-Reinet district. They had succeeded not only in halting the latest colonial encroachments, but also in pushing the colonial border back. Unlike sailors, these rebels believed their freedom could be realized only by remaining independent. The British were seen neither as their rulers nor their allies, and rebels simply did not engage with the Cape's new imperial powers. They could not be enticed to return to the Colony by labour reform, nor could they be defeated militarily. It would not be until I 8 I I-I 8 I 2, when the British military established forts in the area, that the British were able to gain control over the eastern boundary of the Colony.

A third major protest took place in 1808 , during the second British occupation. ${ }^{108}$ The revolt included, besides slaves, a number of KhoiSan servants and two sailors, who, as noted above, played an integral part in

I06. Letter, Macartney to Dundas, 7 July I798, RCC, II, p. 274; Letter, War Office to the Earl of Macartney, Downing Street, is December 1798, RCC, II, p. 3 I 2; and Letter, Major General Dundas to Henry Dundas, Cape of Good Hope, 6 April I799, RCC, II, p. 4I8; Letter, Vice Admiral Curtis to Evan Nepean, Esq., Lancaster, Table Bay, Cape of Good Hope, 6 January I 800, RCC, II, p. I 8 .

107. For a more detailed account see S. Newton-King and V.C. Malherbe, The Khoikhoi Rebellion in the Eastern Cape (1799-1803) (Cape Town, 1981).

108. For a more detailed account see Ulrich, "Abolition from Below", pp. 193-222, and N. Worden, "Armed with Swords and Ostrich Feathers: Militarism and Cultural Revolution in the Cape Slave Uprising of I 808", in Richard Bessel, Nicholas Guyatt, and Jane Rendall (eds), War, Empire and Slavery, $1770-1830$ (London, 2010), pp. I $21-138$. 
organizing the revolt. It was not simply a slave revolt; it was a revolt against slavery, which drew in other sections of the popular classes. Rejecting gradual reform from above, or the amelioration of their condition, the i 808 rebels developed their own vision of immediate and complete emancipation from below. On 27 October, anti-slavery rebels invaded 34 farms in the wealthy grape- and grain-growing districts of the Zwartland, Koeberg, and Tygerberg. ${ }^{109}$ With their tied-up masters in tow, more than 300 rebels marched to Cape Town to demand their freedom and, if necessary, topple the government. ${ }^{\text {IIO }}$

During the revolt, one of the rebel leaders, Abraham van de Kaap, declared "the insurgents the next day would hoist the bloody flag and fight themselves free". ${ }^{\text {II }}$ The bloody flag, or red flag, has important maritime connotations and was traditionally hoisted by sailors in mutiny. ${ }^{\text {II }}$ There is no conclusive evidence, but perhaps due to the connections between sailors, slaves, and KhoiSan, the I 808 rebels may have borrowed the symbol of the red flag from the I797 Cape mutinies.

Through these three protests we see three very different conceptions of rights, freedom, and the state. Sailors in Simon's Bay pressed the Admiralty to implement reforms. However, sailors struggled to reconcile their officers' paternalism and the harshness of capitalist relations. Rejecting a narrow view of rights based on British custom and law, sailors mutinied a second time in Table Bay.

On the other hand, rebels in the Servants' Rebellion and the I 808 revolt did not believe that the imperial state could offer rights or freedom. KhoiSan rebels did not believe that the British government could meet their demands, and sought to realize their freedom by remaining independent and refusing to engage the state. Those who participated in the I 808 revolt also placed little faith in the colonial state. Like rebels in the American, French, and Haitian revolutions, they were determined to topple the government should their demand for freedom not be met.

\section{CONCLUSION}

The 1797 mutinies by British naval sailors were a major contribution to the age of revolution that altered the world forever. Naval sailors fused their established workplace traditions in the Royal Navy with their experiences at the Cape, and the Simon's Bay and Table Bay mutinies intensified class conflict and contributed to popular resistance at a global and local level. Perhaps the most notable development in these Cape

I09. WCPA, CJ 802, p. 752.

I Iо. WCPA, CJ 802, pp. 753-754.

i I I. WCPA, CJ 802, p. 759.

I I 2. Manwaring and Dobrée, Floating Republic, p. 50. 
mutinies is that they demonstrated that sailors were starting to develop new political understandings of their circumstances. Even though they were able to secure improvements, like their brothers at Spithead, these victories appeared to be hollow as long as class exploitation and oppression remained intact. It is within this context that we see sailors starting to break with the particular rhetoric of "free-born Englishmen", used during the Spithead and Simon's Bay mutinies, and question the notion that their rights and liberty resided in British tradition and the courts. 